\title{
Antesedent Dari Online Trust Serta Dampaknya Terhadap Willingness To Choose Konsultasi Online (Studi Empiris Pada Konsumen Aplikasi Layanan Kesehatan)
}

\author{
Rio Alexandro* Ferdi Antonio** \\ *Fakultas Kedokteran Universitas Pelita Harapan, Jakarta \\ **Graduate School of Management, Universitas Pelita Harapan, Jakarta, Indonesia \\ Rioalexsandro1993@gmail.com
}

\begin{abstract}
ABSTRAK
Rumah sakit swasta bersaing dengan cara mengupayakan kualitas pelayanan yang dapat memenuhi berbagai kebutuhan konsumennya. Salah satu unit pelayanan di rumah sakit yang sering terabaikan adalah pelayanan di aplikasi online. Pasien pada jaman sekarang tentunya ingin mendapatkan pelayanan dengan cara yang praktis dan berkualitas. Terutama pada masa pandemi Covid 19 dimana layanan tatap muka dibatasi dan banyak kegiatan dilakukan secara online. Sejauh ini penelitian terkait faktor-faktor yang dapat berpengaruh pada kepuasan konsumen pada pelayanan tersebut masih jarang ditemukan. Untuk mengisi kekosongan tersebut disusun model penelitian yang dimodifikasi dari penelitian terdahulu. Tujuan penelitian ini untuk menguji pengaruh dari professional knowledge, physician rank, treatment effect, physician image, response speed, service commitment, service attitude, communication efforts terhadap cognitive trust dan affective trust serta dampaknya pada willingness to choose. PLS-SEM digunakan untuk menganalisis data empiris yang diperoleh dengan purposive sampling Didapatkan 273 responden yang memenuhi syarat melalui kuesioner yang didistribusikan secara online. Hasil penelitian menunjukkan bahwa professional knowledge dan treatment effect tidak terbukti secara signifikan mempunyai pengaruh positif pada cognitive trust. Service attitude dan communication efforts, tidak terbukti secara signifikan mempunyai pengaruh positif pada afective trust. Physician rank, physician image, dan response speed terbukti signifikan mempunyai pengaruh positif pada cognitive trust. Service commitment terbukti secara signifikan mempunyai dampak positif pada affective trust. Cognitive trust dan affective trust terbukti secara signifikan mempunyai dampak positif pada willingness to choose. Dengan demikian hasil penelitian ini menkonfirmasi teori Kepercayaan pasien terhadap pelayanan dokter dalam melakukan konsultasi kesehatan online baik secara kognitif maupun afektif mempunyai dampak yang nyata pada willingness to choose konsultasi kesehatan online. Model penelitian ini memiliki memiliki moderate predictive accuracy serta medium predictive relevance sehingga dapat dikembangkan dalam penelitian lebih lanjut. Terdapat implikasi manajerial dari temuan penelitian ini serta dan rekomdendasi bagi penelitian selanjutnya.
\end{abstract}

Kata kunci: cognitive trust, affective trust, willingness to choose 


\title{
“ANTESEDENCE FROM ONLINE TRUST TOWARDS WILLINGNES TO CHOOSE ONLINE CONSULTATION “
}

\author{
Rio Alexandro* Ferdi Antonio** \\ *Fakultas Kedokteran Universitas Pelita Harapan, Jakarta, Indonesia, \\ **Graduate School of Management, Universitas Pelita Harapan, Jakarta, Indonesia \\ Rioalexsandro1993@gmail.com
}

\begin{abstract}
Private hospitals compete by seeking quality services that can meet the various needs of their consumers. One of the service units in hospitals that is often neglected is services in online applications. Patients today certainly want to get services in a practical and quality way. Especially during the Covid 19 pandemic where face-to-face services are limited, and many activities are carried out online. So far, research related to the factors that can affect customer satisfaction with these services is still rarely found. To fill the void, a modified research model was developed from previous research. The purpose of this study was to examine the effect of professional knowledge, physician rank, treatment effect, physician image, response speed, service commitment, service attitude, communication efforts on cognitive trust and affective trust and their impact on willingness to choose. PLS-SEM was used to analyze empirical data obtained by purposive sampling. There were 273 respondents who met the requirements through a questionnaire distributed online. The results showed that professional knowledge and treatment effects were not proven to have a significant positive effect on cognitive trust. Service attitude and communication efforts are not proven to have a significant positive effect on affective trust. Physician rank, physician image, and response speed were shown to have a significant positive effect on cognitive trust. Service commitment is proven to have a significant positive impact on affective trust. Cognitive trust and affective trust are proven to have a significant positive impact on willingness to choose. Thus, the results of this study confirm the theory of patient trust in doctor services in conducting online health consultations, both cognitively and affectively, having a real impact on willingness to choose online health consultations. This research model has moderate predictive accuracy and medium predictive relevance so that it can be developed in further research. There are managerial implications of the findings of this study and recommendations for further research.
\end{abstract}

Keywords: cognitive trust, affective trust, willingness to choose 


\section{PENDAHULUAN}

Kesehatan adalah pengalaman kesejahteraan fisik dan psikologis. Kesehatan yang baik dan kesehatan yang buruk tidak terjadi sebagai dikotomi, tetapi sebagai suatu kontinum. Tidak adanya penyakit atau kecacatan diperlukan untuk menghasilkan keadaan kesehatan yang baik.(McCartney et al., 2019) Menurut Deloitte's 2020 Global Healthcare Outlook, sistem perawatan kesehatan di seluruh dunia menghadapi masalah yang sama, yaitu biaya perawatan kesehatan yang meningkat, perubahan demografi pasien, ekspektasi pelanggan yang berkembang, pemain pasar baru, kesehatan yang kompleks dan ekosistem teknologi.(Delloitte, 2020) Sistem Kesehatan yang cerdas meliputi: a) perawatan yang tepat diberikan pada waktu yang tepat, di tempat yang sesuai, untuk pasien yang sesuai; b) penggunaan teknologi untuk mendiagnosis dan mengobati penyakit serta memberikan perawatan secara lebih akurat; c) efisiensi efektivitas dalam komunikasi dan informasi dalam pembiayaan; d) individu yang tepat melakukan pekerjaan yang benar; e) pasien secara aktif terlibat dalam rencana perawatan mereka; dan e) peningkatan efisiensi, penurunan limbah.(Stephanie Allen et al., 2019) Tele-kesehatan merupakan sarana pelayanan kesehatan jarak jauh yang dilakukan oleh tenaga kesehatan dengan memanfaatkan teknologi informasi dan komunikasi. (Kemenkes, 2019) Sistem telekesehatan merupakan bagian integral dari pertukaran informasi perawatan kesehatan elektronik antara pasien dan penyedia.(Bull et al., 2016) Sistem telekesehatan dinilai sangat meningkatkan akses keperawatan, serta kualitas perawatan medis yang diterima.
Selain itu, telehealth telah secara signifikan mengurangi biaya perawatan kesehatan di banyak negara.(Bull et al., 2016) Teknologi yang diimbangi dengan tenaga Kesehatan berkualitas memberikan akses yang dapat menurunkan jumlah diagnosis banding, komplikasi dan meningkatkan manajemen kesehatan.(Sunjaya, 2019) Kesehatan digital berkembang pesat di Indonesia, seperti halnya secara global. Secara global, diperkirakan terdapat lebih dari 318.000 aplikasi kesehatan yang tersedia di Google Play dan toko aplikasi Apple pada tahun 2017. Terdapat lebih dari 200 aplikasi kesehatan ditambahkan setiap hari. Jumlah aplikasi kesehatan di Google Play Store meningkat sebanyak 50\% dari 2016 hingga 2017, sedangkan Apple App store mengalami peningkatan aplikasi Kesehatan sebanyak 20\% setiap tahunnya.(MTPC, 2020) Aplikasi kesehatan terdapat lima aplikasi swasta yang bergerak dalam bidang konsultasi kesehatan daring atau telekonsultasi yang berdiri di Indonesia, yaitu Halodoc, Alo dokter, Medika App, Tele-CTG dan Homecare24.(Deloitte, 2018) Salah satu fenomena digital yang terjadi terdapat pada aplikasi Halodoc sebagai salah satu konsultasi yang paling banyak digunakan. Aplikasi tersebut menempati peringkat ke-2 global dalam kategori kesehatan dan menempati peringkat 49 nasional dengan total sebanyak 30.800 juta pengunjung (traffic). Selain Indonesia, aplikasi tersebut digunakan diberbagai negara dengan penggunaan terbanyak adalah Malaysia $(0,96 \%)$, Amerika Serikat (0,40\%), Singapura $(0,24 \%)$ dan India $(0,24 \%)$.(Similarweb, 2021) Hal ini menunjukkan bahwa kesehatan digital telah 
menarik perhatian masyarakat di Indonesia. Populasi negara yang besar, muda, dan terlibat secara teknologi telah mengadopsi teknologi untuk mengatasi tantangan khususnya pada sektor kesehatan. Seiring pertumbuhan populasi Indonesia dan semakin banyak orang mendapatkan akses ke internet dan smartphone di seluruh negeri, pasar digital di Indonesia akan bertumbuh.(MTPC, 2020) Fenomena kedua yang dijumpai pada konsumen berasal dari survei pendahuluan yang dilakukan pada lima belas pasien yang pernah melakukan konsultasi kesehatan online pada bulan februari 2021. Terdapat tiga pertanyaan pada

Suatu penelitian empiris yang membahas efektivitas penggunaan aplikasi chatbotsebagai fasilitas informasi online tentang tingkat kepuasan pengguna kesehatan primer menunjukkan bahwa sebagian besar responden memiliki kepuasan dalam rentang sangat tinggi atau sangat baik dengan proporsi $44(73,3 \%)$ responden, nilai usability rata-rata 89,9 (> 70$)$ yang menyimpulkan bahwa tingkat kegunaan aplikasi berada pada rentang sangat tinggi. (Falah and Syamsidar, 2021) Kepercayaan (trust) didefinisikan sebagai konsep relasional yang terdiri dari keyakinan (how) tentang orang lain (who) sehubungan dengan masalah tertentu (what) yang muncul dalam kondisi yang tidak diketahui. Kognisi dan tindakan tersebut justru dihasilkan dari kepercayaan dan pengaruh satu sama lain melalui rantai proses dan kausal.(Robbins, 2016) Praktik kedokteran secara inheren merupakan serangkaian aktivitas moral, yang kuesioner dengan pilihan jawaban menggunakan skala 1 sampai 10 . Pertanyaan pada survei pendahuluan ini yaitu: 1) pasien melakukan konsultasi kesehatan online karena dokter yang melakukan pelayanan memenuhi harapannya, 2) pasien melakukan konsultasi kesehatan online karena merasa senang, aman dan nyaman dengan dokter pada aplikasi tersebut serta 3) seberapa bersedia pasien memilih melakukan konsultasi kesehatan online. Dimana nilai 9 sampai 10 dikategorikan sebagai promotor sedangkan nilai 7 sampai 8 dikategorikan pasif. Adapun hasil survei pendahuluan seperti ditampilkan pada tabel di bawah ini

didirikan dalam "perjanjian kepercayaan" antara pasien dan dokter. Dokter dan tenaga medis lainnya perlu memahami agar bagaimana tanggung jawab mendasar ini dapat berperan secara berbeda dalam telekesehatan dibandingkan yang dilakukan dalam interaksi pasien-dokter secara langsung.(Chaet et al., 2017) Kepercayaan daring (online trust) merupakan suatu sikap harapan percaya diri dalam situasi risiko daring bahwa kerentanan seseorang tidak akan dieksploitasi. Secara fundamental, konsep kepercayaan daring dari kepercayaan tatap muka, meskipun suatu harus mempercayai objek yang dibuat oleh individu lainnya.(Bauman and Bachmann, 2017) Penelitian empiris yang menganalisa persepsi sistem telekesehatan oleh mahasiswa menggunakan menemukan bahwa mahasiswa cenderung menggunakan telekesehatan dengan aspek sebagai berikut: (1) sistem bekerja secara efisien, (2) kenyamanan telehealth, dan (3) untuk 
mendapatkan akses ke layanan kesehatan. Hasil penelitian terhadap 295 responden yang menjawab tentang keuntungan telekesehatan didapatkan hsdil ysng memilih keuntungan dari segi aksesibilitas sebanyak $78(26,5 \%)$ responden, kenyamanan $72 \quad(24,4 \%)$ responden, dan efisiensi $63 \quad(21,4 \%)$ responden. Subtema lain dari keunggulan termasuk komunikasi sebanyak $26(8,8 \%)$ responden, keterhubungan $14 \quad(4,8 \%)$, keterjangkauan $7(2,4 \%)$, anonimitas 7 $(2,4 \%)$ responden, dan kegunaan sebanyak 7 $(2,4 \%)$ responden.(Bull et al., 2016) Penelitian dalam bentuk tinjauan literatur mengnalisa bahwa penelitian ini memfokuskan tiga tema penelitian utama (model kepercayaan, faktor teknologi dan sosial yang mempengaruhi kepercayaan online) dan membahas topik di setiap tema utama yang ditemukan dalam studi langsung tentang kepercayaan konsumen daring. Lima puluh empat penelitian dipilih untuk analisis: lima di antaranya meninjau literatur, enam berkontribusi pada pengembangan teori, dan 43 artikel berupa penelitian empiris di bidang kepercayaan online dalam lingkungan komersial. Penelitian ini menunjukkan tidak hanya tren utama dalam penelitian tetapi juga tiga bidang yang belum dipelajari: (1) kepercayaan baru (green trust), pemulihan kepercayaan, dan (3) peran etika dalam mengembangkan kepercayaan daring.(Bauman and Bachmann, 2017) Saat memilih dokter di platform daring, masyarakat umumnya dapat melihat informasi dokter seperti nama, gambar, gelar, dan sebagainya yang membantu pasien dalam proses pengambilan keputusan. Penelitian tersebut menggunakan komponen tersebut sebagai variabel anteseden yang mendorong keinginan masyarakat untuk percaya dalam melakukan konsultasi kesehatan daring. Variabel-variabel anteseden tersebut yaitu: (1) peringkat pengetahuan profesional dokter, yang mewakili pengetahuan profesional; (2) tingkat dan gelar dokter rumah sakit yang mewakili pangkat dokter; (3) peringkat efek pengobatan dokter yang mewakili efek pengobatan; (4) foto dokter yang mewakili citra dokter; (5) tingkat respons 24 jam dokter dalam mewakili kecepatan respons; (6) Komitmen pelayanan dokter untuk membalas banyaknya balasan dalam konsultasi daring; (7) peringkat sikap pelayanan dokter sebagai sikap pelayanan; (8) Peringkat keterampilan komunikasi dokter yang merupakan upaya komunikasi. Berdasarkan informasi atribut dokter tersebut, pasien dapat menciptakan persepsi mereka sendiri tentang kemampuan, integritas, dan kebajikan dokter. Selanjutnya, informasi ini membangkitkan kepercayaan kognitif dan afektif mereka yang memengaruhi kesediaan mereka untuk memilih dokter tertentu.(Wan, Zhang and Yan, 2020) Model penelitian kali ini akan diuji secara empiris pada masyarakat di Indonesia yang melakukan konsultasi Kesehatan secara daring. Hasil analisis model penelitian ini diharapkan dapat memberi kontribusi baru dalam mengkonfirmasi teori anteseden masyarakat dalam kesediaan untuk percaya dan memilih konsultasi Kesehatan daring. Peneliti mengharapkan bahwasannya hasil penelitian ini juga dapat diimplikasikan kepada manajemen konsultasi Kesehatan daring yang dapat disarankan bagi manajer platform konsultasi Kesehatan daring dalam upaya 
meningkatkan kinerja pelayanan Kesehatan daring yang lebih efektif dan terpercaya.

\section{METODE}

Kepercayaan adalah keyakinan bahwa pihak lain kompeten, terbuka, peduli, dan dapat diandalkan. Kepercayaan adalah "keadaan psikologis yang terdiri dari niat untuk menerima kerentanan berdasarkan ekspektasi positif dari niat atau perilaku orang lain". Kepercayaan muncul sebagai isu penting antara dokter dan pasien karena aktivitas medis merupakan hal yang berisiko dan penuh ketidakpastian, dan karena dokter dan pasien mungkin memiliki tujuan dan minat yang berbeda. (Lu et al.,2018) Professional knowledge biasanya tidak hanya berdasarkan pengetahuan deklaratif tetapi juga pengetahuan prosedural. Perbedaan ini mengacu pada penelitian dalam psikologi kognitif: pengetahuan deklaratif dapat diartikulasikan dan bersifat eksplisit, sedangkan pengetahuan prosedural mengacu pada bagaimana melakukan sesuatu dan seringkali bersifat implisit. (Kulgemeyer and Riese, 2018) Di beberapa negara, seperti Cina, ada standar sistem peringkat dokter dan peringkat dokter dinilai oleh organisasi resmi dengan seperangkat kriteria. Kriteria ini termasuk tingkat pendidikan profesional, tahun praktik, publikasi penelitian dan penghargaan, dan ujian standar. Oleh karena itu, status profesional seorang dokter menandakan kekuatan pengetahuan dan hak istimewa yang melekat pada status tersebut. (Lu et al.,, 2018) Sejumlah hambatan penerimaan telehealth yang diidentifikasi di sini mengkonfirmasi persepsi dalam penelitian sebelumnya tentang adanya keterbatasan teknologi, kekhawatiran tentang hubungan inferior antara klienpenyedia dan kurangnya sentuhan fisik.(Campbell et al., 2019) Ekspresi wajah memiliki dampak yang berbeda terhadap emosi, kognisi, dan perilaku orang.(Fagerstrøm et al., 2017) Darwin (1872) menunjukkan bahwa ekspresi wajah menyampaikan informasi mengenai niat perilaku dasar dan kecenderungan emosional organisme (manusia atau hewan) terhadap orang lain.(Fagerstrøm et al., 2017) Response time didefinisikan sebagai waktu yang berlalu dari titik ketika konsumen memposting pengaduan ke titik ketika balasan dari perusahaan diterima. Dalam membangun layanan telemedicine, dibutuhkan adanya teknologi informasi dan komunikasi sebagai infrastruktur yang mendasari.(Khemapech et al., 2019) Komitmen adalah kekuatan yang mengikat seseorang pada tindakan yang relevan dengan satu tujuan atau lebih. Komitmen muncul ketika suatu individu, dengan membuat penilaian, menghubungkan minat yang besar dengan garis aktivitas yang konsisten. (Yahaya and Ebrahim, 2016) Sikap merupakan suatu landasan yang penting dalam suatu usaha karena memengaruhi cara seseorang dalam mengelolah informasi dan berperilaku.(Haddock and Maio, 2017) kepercayaan adalah konsep dinamis yang berkembang dari waktu ke waktu, dipengaruhi oleh peristiwa dan pengalaman masa lalu.(Huang et al., 2019) Kerelaan untuk melakukan konsultasi online dalam konteks kepercayaan kognitif adalah sikap mental yang kompleks yang relatif terhadap serangkaian tujuan dan diekspresikan dalam keyakinan. Kerelaan tersebut mempengaruhi keputusan tentang perilaku masa depan 
individu. Kepercayaan emosional mengacu terutama pada sejauh mana seorang trustor bersedia untuk terbuka kepada trustee dan tidak takut akan bahaya emosional dari kepercayaan tersebut. Kepercayaan interpersonal telah ditujukan sebagai harapan atau sebagai keyakinan tentang pasangan dan/atau sebagai kemauan atau niat perilaku. Definisi ini menekankan peran harapan/kepercayaan atau komponen perilaku dari kepercayaan antar pribadi.(Chandon, 2016) terdapat interaksi positif antara kepercayaan kognitif dan afektif, dan keduanya sangat diperlukan dalam konteks kesediaan pasien untuk memilih dokter dalam layanan konsultasi kesehatan online.(Wan et al.,2019)

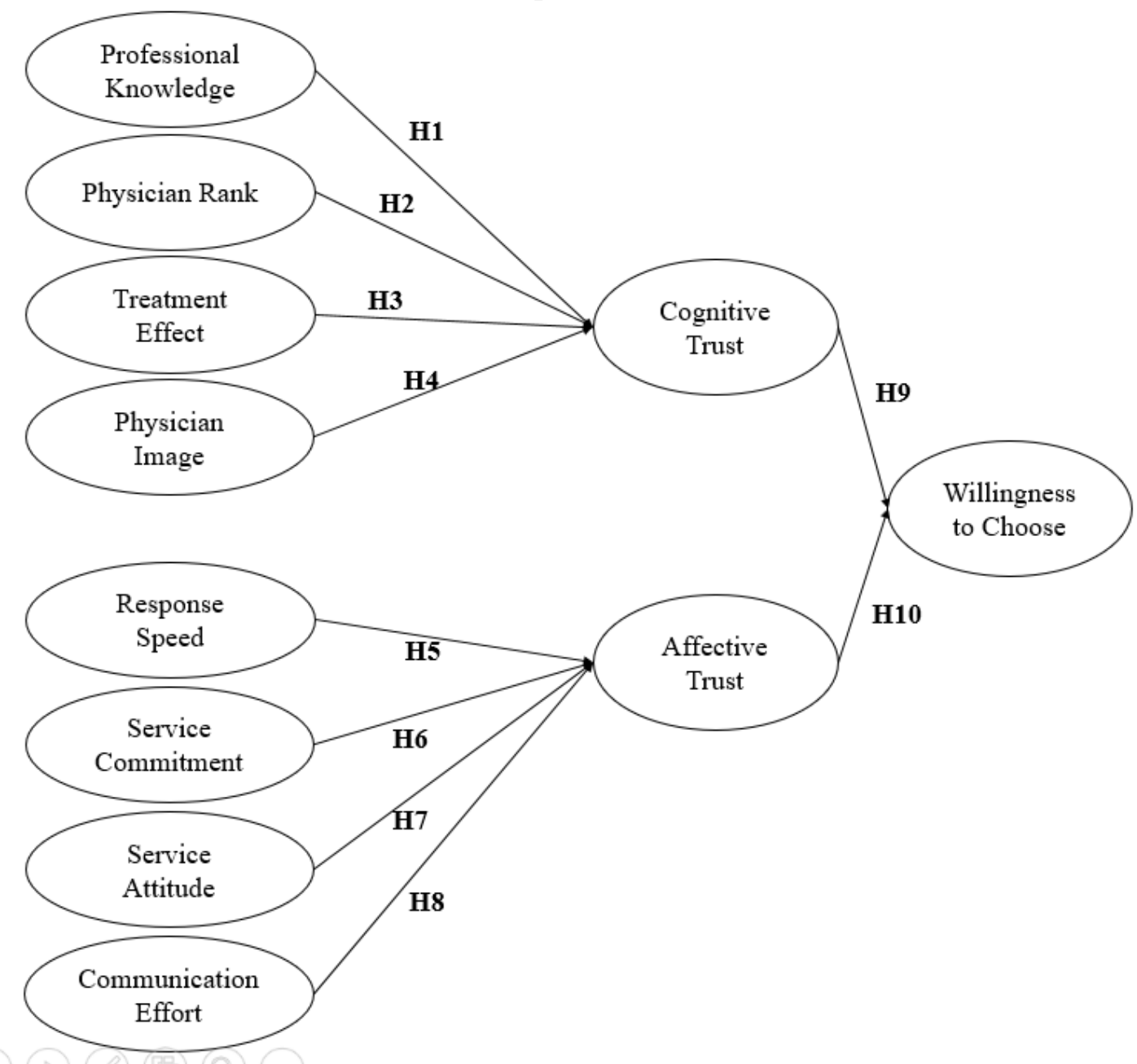

Variabel dalam model penelitian ini diturunkan dari teori tentang pelayanan kesehatan dan kepercayaan pasien, seperti yang telah diuraikan pada bab ini. Karenanya dapat dikatakan bahwa ketersediaan atau willingness menjadi target konstruk dalam penelitian ini. Dalam model penelitian ini terdapat delapan variabel independent yang mewakili proses pelayanan yaitu professional knowledge, physician rank, treatment effect, physician image, response speed, service commitment, service attitude, dan communication effort. Sedangakan sebagai variabel dependent adalah willingness to 
choose atau kesediaan pasien dalam berkonsultasi. Adapun variabel mediasi (intervening variable) terdiri dari cognitive trust dan affective trust yang mewakili kepercayaan dari pasien terhadap tenaga kesehatan yang terlibat dalam pelayanan konsultasi online. Model penelitian ini akan diuji secara empiris terhadap populasi pasien yang melakukan konsultasi secara online di area Jakarta dan sekitarnya. Responden yang digunakan dalam penelitian ini adalah pasien yang melakukan konsultasi online. Para responden memiliki empat kriteria wajib yang harus dipenuhi: pertama adalah bahwa responden adalah masyarakat yang memakai jasa dari layanan konsultasi kesehatan online. Kedua adalah penggunaan jasa layanan konsultasi kesehatan tersebut terjadi dalam satu tahun terakhir dari April - Mei 2021. Ketiga, responden telah berusia lebih dari 17 tahun saat mengisi kuesioner. Dalam penelitian ini unit analisis yang digunakan adalah konsumen aplikasi layanan konsultasi kesehatan. Tipe penelitian ini berdasarkan jenisnya adalah penelitian kuantitatif dengan uji hipotesis (hypothesis test). Tipe penelitian ini berdasarkan jenisnya adalah penelitian kuantitatif dengan uji hipotesis (hypothesis test). Dalam penelitian ini terdapat tiga jenis variabel, yaitu variabel terikat atau dependen (dependent variable), variabel bebas atau independen (independent variable), serta variabel penghubung (mediating atau intervening variable). Dalam penelitian ini digunakan skala Likert dengan 5 poin. Skala Likert merupakan skala yang paling umum digunakan dalam penelitian sosial termasuk dalam penelitian manajemen. Skala Likert ini menggunakan lima poin dengan tingkatan dari satu (1) yaitu sangat tidak setuju, dua (2) yaitu tidak setuju, tiga (3) yaitu netral, empat (4) yaitu setuju, dan lima (5) yaitu sangat setuju. Definisi konseptual dan operasionalisasi dari variabel-variabel di penelitian ini, beserta sumbernya dirangkum dalam tabel dibawah ini:

Tabel 3.1. Definisi konseptual dan operasionalisasi variabel

\begin{tabular}{|c|c|c|c|}
\hline Variabel & Definisi Konseptual & Operasionalisasi Variabel & Sumber/Skala \\
\hline $\begin{array}{l}\text { Professional } \\
\text { knowledge }\end{array}$ & $\begin{array}{l}\text { Professional knowledge } \\
\text { merupakan pengetahuan } \\
\text { yang tidak hanya } \\
\text { berdasarkan pengetahuan } \\
\text { deklaratif tetapi juga } \\
\text { pengetahuan prosedural. } \\
\text { (Kulgemeyer and Riese, } \\
\text { 2018) }\end{array}$ & $\begin{array}{l}\text { 1. Dokter di aplikasi tersebut } \\
\text { memiliki pengetahuan yang } \\
\text { relevan untuk menjawab } \\
\text { pertanyaan yang diajukan } \\
\text { pasien } \\
\text { 2. Dokter di aplikasi tersebut } \\
\text { memiliki pengalaman medis } \\
\text { yang relevan untuk } \\
\text { memecahkan masalah yang } \\
\text { dikonsultasikan pasien } \\
\text { 3. Dokter di aplikasi tersebut telah }\end{array}$ & $\begin{array}{l}\text { (Wan, Zhang } \\
\text { and Yan, 2020) } \\
\text { Skala Likert (1 } \\
\text { s/d 5) }\end{array}$ \\
\hline Physician rank & $\begin{array}{l}\text { Status profesional dapat } \\
\text { ditunjukkan dengan } \\
\text { pangkat atau gelar yang } \\
\text { dipegang oleh seorang }\end{array}$ & $\begin{array}{l}\text { 1. Dokter yang dipilih memiliki } \\
\text { status yang tinggi atau } \\
\text { bereputasi tinggi di rumah sakit } \\
\text { tempat dokter tersebut bekerja }\end{array}$ & $\begin{array}{c}\text { (Wan, Zhang } \\
\text { and Yan, 2020) }\end{array}$ \\
\hline
\end{tabular}




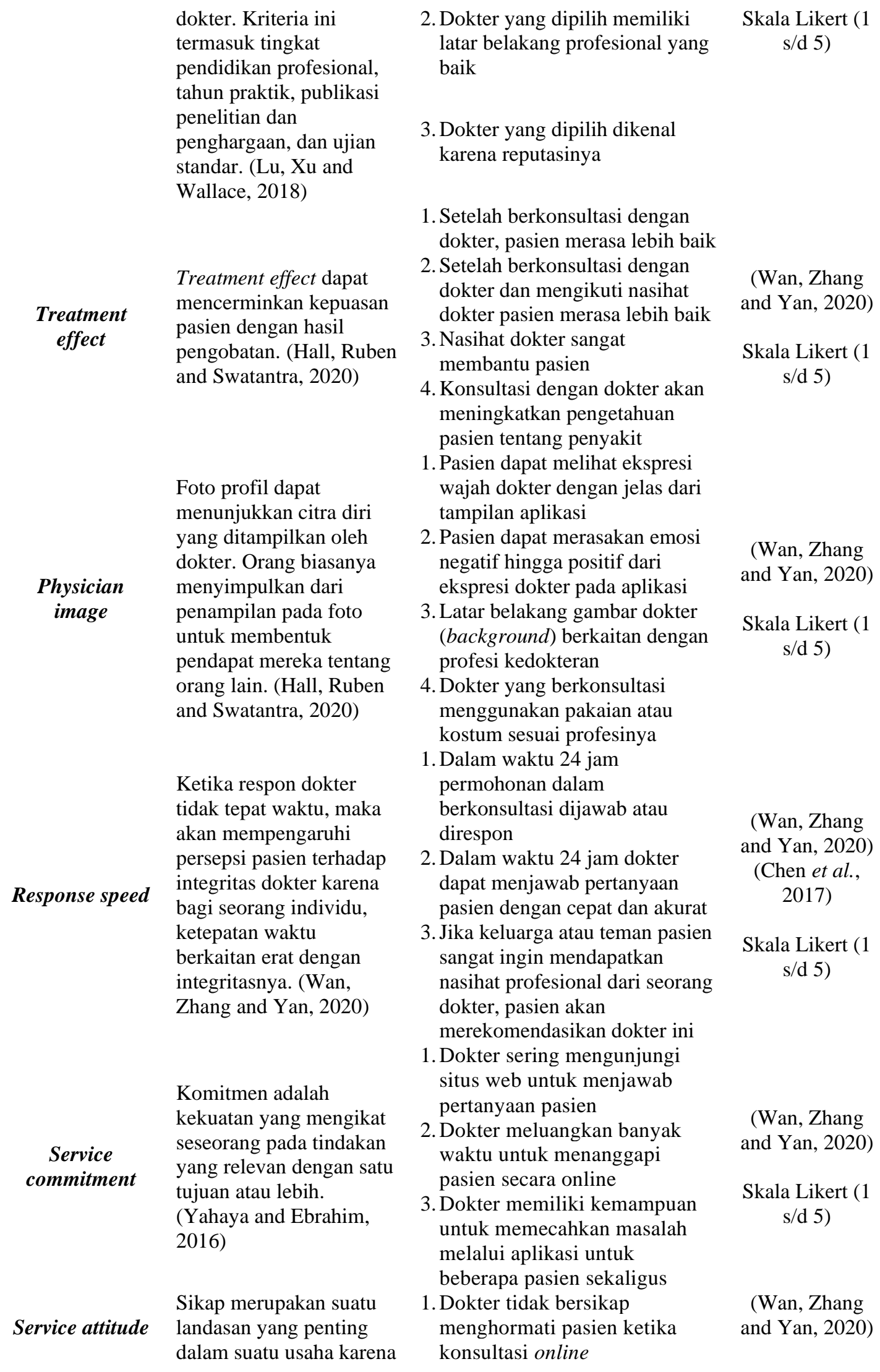

dokter. Kriteria ini termasuk tingkat pendidikan profesional, tahun praktik, publikasi standar. (Lu, $\mathrm{Xu}$ and allace, 2018

Treatment effect dapat pasien dengan hasil pengobatan. (Hall, Ruben and Swatantra, 2020)

Foto profil dapat menunjukkan citra diri yang ditampilkan oleh dokter. Orang biasanya pendapat mereka tentang orang lain. (Hall, Ruben and Swatantra, 2020)

Ketika respon dokter tidak tepat waktu, maka akan mempengaruhi ketepatan waktu berkaitan erat dengan integritasnya. (Wan, Zhang and Yan, 2020)

Komitmen adalah kekuatan yang mengikat Yahaya and Ebrahim

Sikap merupakan suatu dalam suatu usaha karena

\section{Dokter yang dipilih memiliki latar belakang profesional yang \\ Dokter yang dipilih dikenal karena reputasinya}

. Setelah berkonsultasi dengan

Setelah berkonsultasi dengan dokter dan mengikuti nasihat

Nasihat dokter sangat

membantu pasien

Konsultasi dengan dokter akan meningkatkan pengetahuan nenyakit wajah dokter dengan jelas dari tampilan aplikasi

. Pasien dapat merasakan emosi negatif hingga positif dari ekspresi dokter pada aplikas

. Latar belakang gambar dokter (background) berkaitan dengan profesi kedokteran

Dokter yang berkonsultasi menggunakan pakaian atau tum sesuai profesinya

permohonan dalam berkonsultasi dijawab atau direspon

Dalam waktu 24 jam dokte dapat menjawab pertanyaan

. Jika keluarga atau teman pasien sangat ingin mendapatkan nasihat profesional dari seorang dokter, pasien akan pertanyaan pasien

Dokter meluangkan banya pasien secara online

Dokter memiliki kemampua melalui aplikasi untuk beberapa pasien sekaligu menghormati pasien ketika

\section{Skala Likert (1}

\author{
(Wan, Zhang
}

Skala Likert (1
s/d 5)

(Wan, Zhang

Skala Likert (1
s/d 5)

and Yan, 2020)

(Chen et al., 2017)

Skala Likert (1

\author{
(Wan, Zhang \\ and Yan, 2020) \\ Skala Likert (1 \\ d 5) \\ (Wan, Zhang \\ and Yan, 2020)
}


dapat memengaruhi cara seseorang dalam mengelolah informasi dan berperilaku. (Haddock and Maio, 2017)

Fungsi memberikan informasi merupakan kegiatan yang bertujuan

Communication efforts

\section{Affective trust}

Cognitive trust mengumpulkan data dan informasi agar seseorang dapat mengerti tugas yang harus dilakukan. (Dwyer, 2018)

Kepercayaan kognitif didefinisikan sebagai keyakinan yang dipegang oleh konsumen bahwa

\section{konsumen dapat} diandalkan, kompeten, dan dapat memenuhi janjinya. (Punyatoya, 2019)

Kepercayaan afektif didefinisikan sebagai keyakinan bahwa konsumen menempatkan diri kepada produsen atas dasar naluri, intuisi atau perasaan yang dihasilkan oleh tingkat kepedulian dan perhatian yang ditunjukkan oleh pemberi jasa online. (Punyatoya, 2019)

Pengambilan keputusan oleh seorang pasien untuk mempercayai seorang dokter,

Willingness to Choose kepercayaan ini selanjutnya mempengaruhi niat perilaku mereka, yaitu kesediaan pasien untuk memilih. (Wan, Zhang and Yan, 2020)

2. Dokter bersikap ramah

Skala Likert (1
s/d 5)

3. Dokter bersikap kurang baik selama online

1. Dokter akurat menyampaikan informasi yang ingin

diungkapkannya

2. Dokter dapat memahami kebutuhan saya serta berinteraksi dengan pasien secara efektif

3. Dokter dapat membuat saya memahami apa yang ingin dia ungkapkan

1. Dokter melakukan pekerjaannya dengan profesionalisme dan dedikasi

2. Kemampuan dokter tersebut tidak diragukan

3. Dokter tidak lalai

4. Kebanyakan orang akan menghormati dan mempercayai dia sebagai seorang dokter

1. Dokter memperlakukan pasien seperti seorang teman, bebas untuk berbagi pikiran, perasaan serta harapan satu sama lain

2. Dokter memperhatikan dan menunjukkan perhatian yang cukup

3. Tidak dapat memilih dokter yang pasien harapkan

4. Dokter antusias, bertanggung jawab, memberi nasihat yang berguna serta perhatian

5. Dokter bersedia untuk mempertimbangkan kepentingan kedua belah pihak serta memberikan perhatian untuk menjaga hubungan dokter-pasien

1. Pasien akan memilih dokter tersebut kembali bila pasien tersebut berkonsultasi online

2. Memilih dokter tersebut adalah ide yang kurang baik

3. Dokter tersebut layak untuk direkomendasikan kepada keluarga atau teman saya
(Wan, Zhang

and Yan, 2020)

Skala Likert (1 s/d 5)

(Wan, Zhang

and Yan, 2020)

Skala Likert (1 s/d 5)

(Wan, Zhang and Yan, 2020)

Skala Likert (1 s/d 5)

(Wan, Zhang and Yan, 2020)

(Obele et al., 2017)

Skala Likert (1 s/d 5)

Sumber: Hasil pengolahan data penelitian (2021) 
besar sampel minimum yang dibutuhkan dalam penelitian ini adalah sebanyak 96 responden. Namun berdasarkan pendekatan sampel minimal untuk metode partial least square - structural equation modelling (PLSSEM) dari (Kock and Hadaya, 2018), apabila menggunakan metode penghitungan akar kuadrat terbalik (inverse square root method), maka besar sampel minimal yang diperlukan minimal 160 responden. Pengambilan sampel dengan metode purposive sampling ini dibatasi bagi individu tertentu yang dapat memberikan informasi yang diinginkan, baik karena merekalah yang memilikinya, atau mereka sesuai dengan beberapa kriteria yang ditetapkan dalam penelitian. Dalam tahap analisis data pada PLS-SEM, tahap pertama yang dilakukan adalah evaluasi outer model atau model pengukuran dengan melihat hubungan antara 59 indikator dengan variabel laten-nya. (Hair et al., 2018) Outer model ini didapatkan dari hasil kalkulasi PLS Algorithm pada SmartPLS ${ }^{\text {TM }}$. Analisis model pengukuran ini terdiri dari dua bagian, yaitu uji reliabilitas dan uji validitas. Pada uji reliabilitas dilihat dua penilaian yaitu indicator reliability dengan melihat nilai outer loading dan construct reliability dengan melihat nilai Cronbach's alpha dan composite realibility. Selanjutnya pada uji validitas dilihat dua penilaian pula yaitu construct validity dengan melihat average variance extracted (AVE), dan discriminant validity dengan melihat nilai heterotrait-monotrait ratio (HT/MT). Apabila ke-empat parameter tersebut telah memenuhi syarat reliabilitas dan validitas maka barulah dapat dilanjutkan ke tahap analisis berikutnya. (Hair et al., 2018) Inner model atau model struktural merupakan model yang dapat menunjukkan hubungan antar variabel laten dalam suatu model penelitian. Tahap pertama dalam evaluasi model struktural dilakukan dengan melihat kualitas model. Hal ini dilakukan dengan melihat nilai variance inflation factor (VIF) untuk menilai ada tidaknya masalah multikolineritas. Selanjutnya dengan melihat nilai koefisien determinasi atau R2. Nilai ini untuk menentukan kemampuan explanatory dan prediksi model yang diajukan untuk diuji empiris. Nilai R2 berkisar dari 0 hingga 1 dimana nilai yang lebih tinggi akan menunjukkan tingkat akurasi prediksi yang lebih tinggi pula. Menurut Hair dkk. (2018), nilai R2 bisa dibagi menjadi tiga tingkatan yaitu $0,75,0,5$, dan 0,25 sebagai substantial, moderat dan lemah. Langkah selanjutnya dengan menilai Q2 atau 60 predictive relevance yang dimiliki suatu model penelitian. Analisis ini dapat dipertajam juga dengan nilai Q2_predict. Predictive relevance digunakan untuk memvalidasi kemampuan prediksi suatu model bila terjadi perubahan data. Apabila nilai Q2_predict lebih dari nol, maka dapat dikatakan bahwa model struktural memiliki prediksi yang relevan bila terdapat perubahan pada data yang digunakan dalam analisis. Sebaliknya jika nilai Q2_predict kurang dari nol maka menunjukkan bahwa model penelitian tidak memiliki prediksi yang relevan. Setelah dilakukan evaluasi model penelitian maka dilanjutkan dengan tahapan terpenting yaitu tahap pengujian hipotesis. Tahapan ini didapatkan dari menu bootstrap atau resampling pada SmartPLS ${ }^{\mathrm{TM}}$. Adapun pengujian ini dilakukan dengan melihat dua penilaian. Pertama dengan menguji signifikansi hubungan antara variabel dengan 
menggunakan perbandingan nilai $\mathrm{T}$-tabel dengan T-statistic yang dihasilkan dalam uji empiris. Jika T-statistic nilainya lebih tinggi dibandingkan nilai T-tabel, maka pengaruh variabel tersebut dikatakan signifikan. Dalam penelitian ini digunakan tingkat signifikansi $\alpha=0,05$, dengan degree of freedom digolongkan infinity maka nilai T-tabel untuk hipotesis one-tailed adalah 1,645 (Chin, 1988). Selanjutnya dengan melihat nilai koefisien yang dihasilkan melalui bootstrapping. Bila diketahui bahwa terdapat pengaruh yang signifikan dan arah koefisien yang telah sesuai dengan hipotesis maka dapat disimpulkan bahwa hipotesis didukung (supported). Setelah pengujian hipotesis tersebut dapat dilakukan analisis jalur atau path lebih untuk menganalisis kekuatan jalur yang melalui variabel mediasi. Hal ini dilakukan untuk 61 melihat juga kemampuan mediasi dari variabel-variabel mediasi yang ada dalam model penelitian. Analisis ini dapat dilakukan dengan melihat nilai specific indirect. Tahap terakhir yang dapat dilakukan dalam analisis dengan SmartPLS ${ }^{\mathrm{TM}}$ adalah dengan menu IPMA atau ImportancePerformance Map Analysis (IPMA). Analisis ini mengabungkan analisis deskriptif yang menggunakan nilai mean dangan analisis inferensial dengan menggunakan nilai total effect. Gabungan data tersebut digambarkan dalam peta atau mapping dengan dua aksis dimana posisi variabel dan indikator dapat dipetakan dalam gambar tersebut. (Sarstedt and Christian M. Ringle, 2017) Karenanya IPMA dapat membantu menemukan faktor apa yang perlu ditingkatkan (improvement) misalnya karena sudah dianggap penting namun belum menunjukkan kinerja yang baik dan sebaliknya. Dengan demikian IPMA dapat memberi masukan manajerial hal-hal apa yang harus diprioritaskan oleh manajemen rumah sakit.

\section{HASIL}

Dari 273 responden yang telah memenuhi kriteria penelitian didapatkan gambaran profil responden sebagai berikut.

Tabel 4.1. Profil demografi responden

\begin{tabular}{|c|c|c|c|}
\hline Deskripsi & Kategori & Jumlah & Persentase (\%) \\
\hline \multirow{2}{*}{ Jenis kelamin } & Laki-laki & 72 & 26 \\
\hline & Perempuan & 201 & 74 \\
\hline \multicolumn{2}{|r|}{ Total } & 273 & 100 \\
\hline \multirow{5}{*}{ Usia } & $<20$ tahun & 181 & 66 \\
\hline & 21-30 tahun & 76 & 28 \\
\hline & 31-40 tahun & 9 & 3 \\
\hline & 41-50 tahun & 3 & 1 \\
\hline & 51-60 tahun & 4 & 2 \\
\hline \multirow{4}{*}{ Domisili } & Total & 273 & \\
\hline & Jabodetabek & 205 & 75 \\
\hline & Luar Jabodetabek & 68 & 25 \\
\hline & Total & 273 & 100 \\
\hline \multirow{4}{*}{ Pekerjaan } & Profesional & 0 & 0 \\
\hline & Atlet profesional & 3 & 1 \\
\hline & Karyawan swasta & 19 & 7 \\
\hline & PNS/TNI/POLRI & 3 & 1 \\
\hline
\end{tabular}




\begin{tabular}{|c|c|c|c|}
\hline & Wiraswasta & 13 & 5 \\
\hline & Ibu rumah tangga & 10 & 4 \\
\hline & Mahasiswa/pelajar & 222 & 81 \\
\hline & Lainnya & 3 & 1 \\
\hline \multicolumn{2}{|c|}{ Total } & 273 & 100 \\
\hline \multirow{6}{*}{ Pendidikan terakhir } & SMA & 207 & 76 \\
\hline & Diploma & 11 & 4 \\
\hline & $\mathrm{S} 1$ & 42 & 15 \\
\hline & Profesi Ners & 2 & 1 \\
\hline & Profesi Dokter & 4 & 1 \\
\hline & Lainnya & 7 & 3 \\
\hline \multicolumn{2}{|c|}{ Total } & 273 & 100 \\
\hline \multirow{4}{*}{$\begin{array}{l}\text { Pengeluaran rumah } \\
\text { tangga per bulan }\end{array}$} & $<5$ juta & 180 & 66 \\
\hline & 5-10 juta & 55 & 20 \\
\hline & $10-15$ juta & 24 & 9 \\
\hline & $>15$ juta & 14 & 5 \\
\hline \multicolumn{2}{|c|}{ Total } & 273 & 100 \\
\hline
\end{tabular}

Sumber: Hasil pengolahan data penelitian (2021)

Dari total 273 responden, berdasarkan tabel 4.1. di atas terdapat $74 \%$ responden yang berjenis kelamin perempuan dan sebanyak 36\% adalah laki-laki. Hal tersebut menunjukkan bahwa penggunaan aplikasi layanan kesehatan didominasi oleh salah satu jenis kelamin tertentu, yaitu jenis kelamin perempuan. Dari penyebaran usia, didapatkan sebanyak $66 \%$ berusia $<20$ tahun dan $34 \%$ berusia 21 tahun ke atas. Hasil ini memperlihatkan bahwa orang yang memiliki usia muda cenderung memakai aplikasi layanan kesehatan. Hal tersebut dapat dihubungkan dengan banyaknya masyarakat berusia muda yang lebih sering menggunakan gadget serta aplikasi-aplikasi secara online. Mayoritas responden yaitu sebanyak $75 \%$ tinggal di Jabodetabek dan $25 \%$ sisanya berdomisili di luar Jabodetabek. Hasil ini dapat terjadi karena umumnya penduduk di Jabodetabek lebih termodernisasi dan umumnya lebih menyukai hal yang praktis sehingga mereka lebih terbuka akan teknologi baru seperti aplikasi layanan kesehatan. Dari segi pekerjaan, mayoritas adalah mahasiswa/pelajar yaitu sebanyak $81 \%$ dan $19 \%$ sisanya yang memiliki pekerjaan lain. Hasil ini sejalan dengan data demografi usia responden yang didominasi oleh usia <20 tahun sehingga kebanyakan masih berstatus mahasiswa/pelajar. Pendidikan terakhir dari para responden yang terbanyak adalah SMA yaitu sebanyak $76 \%$, sebanyak $15 \%$ adalah $\mathrm{S} 1$, dan sisanya menempuh pendidikan terakhir berupa diploma, profesi ners/dokter, maupun pendidikan lainnya. Hasil ini juga sesuai dengan data demografi dari mayoritas yang berusia $<20$ tahun dan masih menempuh pendidikan sebagai mahasiswa/pelajar. Sebanyak $66 \%$ responden yang memiliki pengeluaran rumah tangga per bulan sebesar <5 juta, sedangkan $34 \%$ lainnya memiliki pengeluaran di atas 
dari 5 juta rupiah. Dengan demikian informasi profil konsumen tersebut dapat memberikan masukan bagi manajemen dalam mempersiapkan fasilitas sesuai data demografi konsumen dan menyusun rencana pemasaran aplikasi layanan kesehatan, misalnya melalui social media yang dikunjungi atau dipakai oleh orang banyak sesuai dengan target konsumennya tersebut.

Tabel 4.13. Discriminant validity

\begin{tabular}{|c|c|c|c|c|c|c|c|c|c|c|c|}
\hline Variabel & $\begin{array}{l}\text { Affec } \\
\text { tive } \\
\text { trust }\end{array}$ & $\begin{array}{c}\text { Cogni } \\
\text { tive } \\
\text { trust }\end{array}$ & $\begin{array}{l}\text { Communi } \\
\text { cation } \\
\text { efforts }\end{array}$ & $\begin{array}{c}\text { Physic } \\
\text { ian } \\
\text { image }\end{array}$ & $\begin{array}{l}\text { Physic } \\
\text { ian } \\
\text { rank }\end{array}$ & $\begin{array}{c}\text { Professi } \\
\text { onal } \\
\text { knowled } \\
\text { ge }\end{array}$ & $\begin{array}{c}\text { Respo } \\
\text { nse } \\
\text { speed }\end{array}$ & $\begin{array}{c}\text { Servi } \\
\text { ce } \\
\text { attit } \\
\text { ude }\end{array}$ & $\begin{array}{c}\text { Service } \\
\text { commit } \\
\text { ment }\end{array}$ & $\begin{array}{l}\text { Treat } \\
\text { ment } \\
\text { effect }\end{array}$ & $\begin{array}{l}\text { Willing } \\
\text { ness to } \\
\text { Choose }\end{array}$ \\
\hline $\begin{array}{c}\text { Affective } \\
\text { trust }\end{array}$ & 0,819 & & & & & & & & & & \\
\hline $\begin{array}{c}\text { Cognitive } \\
\text { trust }\end{array}$ & 0,425 & 0,819 & & & & & & & & & \\
\hline $\begin{array}{l}\text { Communi } \\
\text { cation } \\
\text { efforts }\end{array}$ & 0,439 & 0,457 & 0,998 & & & & & & & & \\
\hline $\begin{array}{l}\text { Physician } \\
\text { image }\end{array}$ & 0,430 & 0,392 & 0,388 & 0,855 & & & & & & & \\
\hline $\begin{array}{l}\text { Physician } \\
\text { rank }\end{array}$ & 0,487 & 0,327 & 0,145 & 0,311 & 0,881 & & & & & & \\
\hline $\begin{array}{c}\text { Profession } \\
\text { al } \\
\text { knowledge }\end{array}$ & 0,499 & 0,244 & 0,175 & 0,355 & 0,399 & 0,817 & & & & & \\
\hline $\begin{array}{c}\text { Response } \\
\text { speed }\end{array}$ & 0,391 & 0,632 & 0,556 & 0,454 & 0,513 & 0,290 & 0,841 & & & & \\
\hline $\begin{array}{l}\text { Service } \\
\text { attitude }\end{array}$ & 0,243 & 0,602 & 0,439 & 0,342 & 0,382 & 0,133 & 0,773 & $\begin{array}{c}0,99 \\
4\end{array}$ & & & \\
\hline $\begin{array}{c}\text { Service } \\
\text { commitme } \\
n t\end{array}$ & 0,490 & 0,462 & 0,677 & 0,492 & 0,329 & 0,370 & 0,637 & $\begin{array}{c}0,49 \\
7\end{array}$ & 0,996 & & \\
\hline $\begin{array}{c}\text { Treatment } \\
\text { effect }\end{array}$ & 0,424 & 0,231 & 0,267 & 0,402 & 0,538 & 0,297 & 0,404 & $\begin{array}{c}0,30 \\
7\end{array}$ & 0,456 & 0,929 & \\
\hline $\begin{array}{c}\text { Willingnes } \\
\text { s to } \\
\text { Choose }\end{array}$ & 0,497 & 0,599 & 0,569 & 0,387 & 0,283 & 0,190 & 0,645 & $\begin{array}{c}0,56 \\
6\end{array}$ & 0,565 & 0,284 & 0,932 \\
\hline
\end{tabular}

Sumber: Hasil pengolahan data PLS-SEM penelitian (2021)

Pada tabel di atas dapat dilihat hasil uji discriminant validity dimana didapatkan nilai rasio heterotrait-monotrait (HT/MT) dari hampir keseluruhan variabel di bawah 0,9. Namun, ditemukan pada lima variabel yang memiliki rasio HT/MT lebih dari 0,9 yaitu pada konstruk communication efforts, service attitude, service commitment, treatment effect, dan willingness to choose. Sehingga dapat dikatakan bahwa maka kelima konstruk tersebut memiliki nilai diskriminan yang tidak valid. Dapat diartikan bahwa indikator-indikator pada variabelvariabel tersebut belum tepat dan belum secara spesifik untuk dapat mengukur konstruknya tersebut. Berdasarkan data 
tersebut dapat disimpulkan bahwa tidak semua indikator pada model penelitian telah terdiskriminasi dengan baik sehingga dapat belum semuanya dapat mengukur konstruknya masing-masing serta tidak semua indikator tersebut telah dengan tepat atau spesifik mengukur konstruknya masingmasing. Berdasarkan empat parameter hasil pengujian reliabilitas dan validitas pada outer model seperti diatas yaitu indicator reliability (outer loading), construct reliability (Cronbach's alpha dan composite reliability), construct validity (average variance extracted atau AVE), dan discriminant validity (heterotrait-monotrait ratio) dapat diambil suatu kesimpulan umum, yaitu bahwa pada model pengukuran penelitian ini (measurement model) tidak semua dari indikatornya reliabel dan valid untuk mengukur konstruknya masing-masing secara spesifik, dengan demikian belum layak untuk dilanjutkan dalam tahap analisis berikutnya yaitu uji inner model (model struktural).

Tabel 4.18 Hasil Uji Hipotesis dan Koefisien

\begin{tabular}{|c|c|c|c|c|}
\hline & $\begin{array}{c}\text { Standardized } \\
\text { Coefficient }\end{array}$ & T-statistics & Signifikansi & Hasil \\
\hline $\begin{array}{l}\text { Affective Trust -> } \\
\text { Willingness to Choose }\end{array}$ & 0.296 & 5,129 & Signifikan & $\begin{array}{l}\text { Hipotesis } \\
\text { didukung }\end{array}$ \\
\hline $\begin{array}{l}\text { Cognitive Trust -> } \\
\text { Willingness to Choose }\end{array}$ & 0.474 & 9,925 & Signifikan & $\begin{array}{l}\text { Hipotesis } \\
\text { didukung }\end{array}$ \\
\hline $\begin{array}{l}\text { Communication Efforts } \\
\text {-> Affective Trust }\end{array}$ & 0.178 & 1,184 & Tidak Signifikan & $\begin{array}{l}\text { Hipotesis } \\
\text { tidak } \\
\text { didukung }\end{array}$ \\
\hline $\begin{array}{l}\text { Physician Image -> } \\
\text { Cognitive Trust }\end{array}$ & 0.317 & 5,302 & Signifikan & $\begin{array}{l}\text { Hipotesis } \\
\text { didukung }\end{array}$ \\
\hline $\begin{array}{l}\text { Physician Rank -> } \\
\text { Cognitive Trust }\end{array}$ & 0.225 & 4,194 & Signifikan & $\begin{array}{l}\text { Hipotesis } \\
\text { didukung }\end{array}$ \\
\hline $\begin{array}{l}\text { Professional } \\
\text { Knowledge -> } \\
\text { Cognitive Trust }\end{array}$ & 0.052 & 0,973 & Tidak Signifikan & $\begin{array}{l}\text { Hipotesis } \\
\text { tidak } \\
\text { didukung }\end{array}$ \\
\hline $\begin{array}{l}\text { Response Speed -> } \\
\text { Affective Trust }\end{array}$ & 0.213 & 1,912 & Signifikan & $\begin{array}{l}\text { Hipotesis } \\
\text { didukung }\end{array}$ \\
\hline $\begin{array}{l}\text { Service Attitude -> } \\
\text { Affective Trust }\end{array}$ & -0.154 & 1,1767 & Signifikan & $\begin{array}{l}\text { Hipotesis } \\
\text { tidak } \\
\text { didukung }\end{array}$ \\
\hline $\begin{array}{l}\text { Service Commitment -> } \\
\text { Affective Trust }\end{array}$ & 0.311 & 4,011 & Signifikan & $\begin{array}{l}\text { Hipotesis } \\
\text { didukung }\end{array}$ \\
\hline
\end{tabular}




$\begin{array}{lccc}\text { Treatment Effect }-> & 0,458 & \text { Tidak Signifikan } & \text { Hipotesis } \\ \text { Cognitive Trust } & -0.032 & & \text { tidak } \\ & & \text { didukung }\end{array}$

Sumber: Hasil pengolahan data PLS-SEM penelitian (2021)

Model penelitian ini telah diuji secara

empiris pada pasien yang melakukan konsultasi Kesehatan online untuk menjawab pertanyaan, apakah professional knowledge, physician rank, treatment effect, physician image, response speed, service commitment, service attitude, dan communication effort sebagai variabel independent yang dimediasi oleh cognitive trust dan affective trust untuk memberikan dampak terhadap willingness to choose? Dari data yang dikumpulkan serta dianalisis dengan PLS-SEM, dapat digambarkan suatu model hasil penelitian seperti berikut ini; 


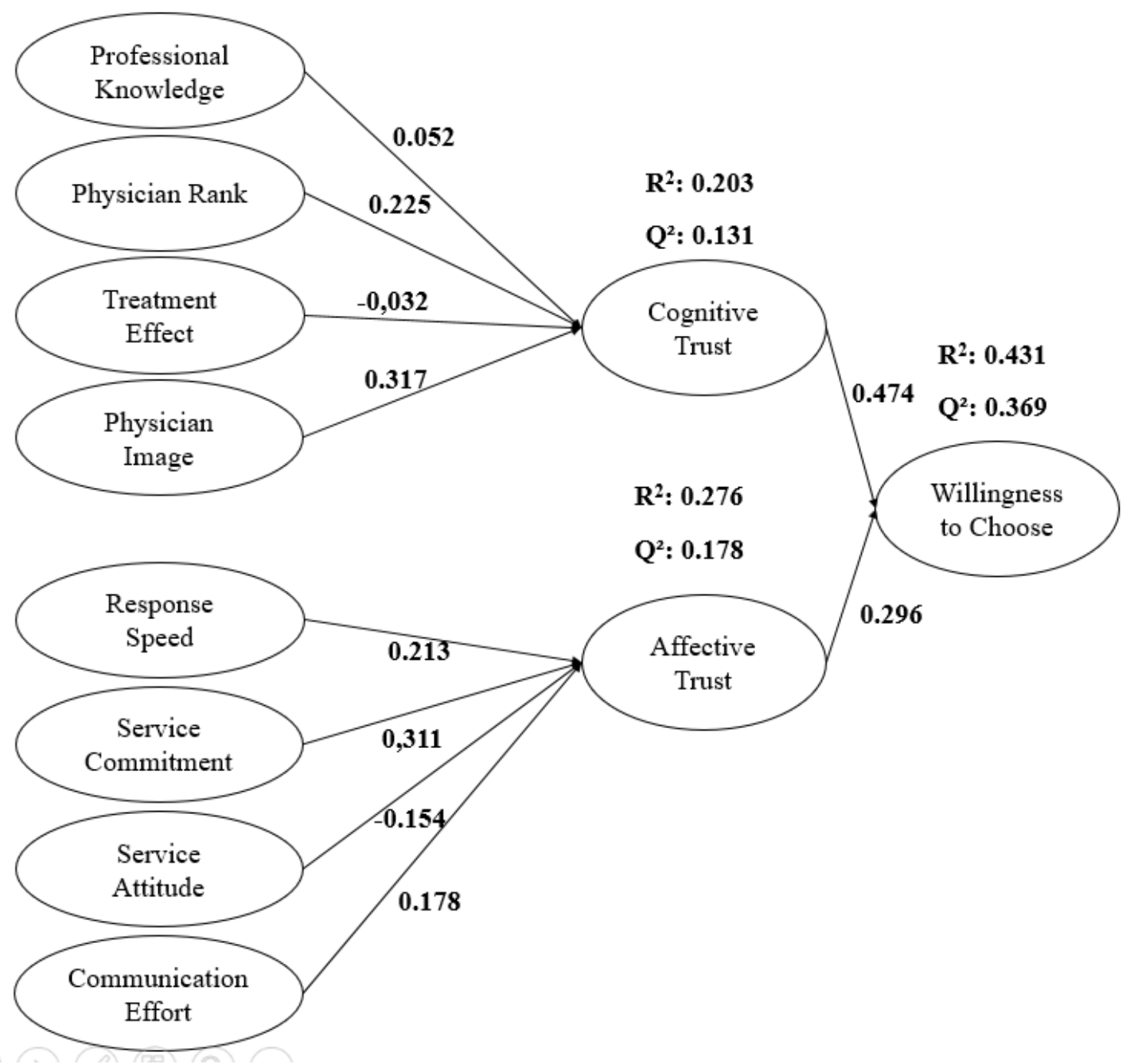

Gambar 4.10 Model Hasil (Empirical Model)

Sumber: Hasil pengolahan data PLS-SEM penelitian (2021)

Kedua variabel mediasi baik dari cognitive trust dan affective trust menunjukkan pengaruh yang signifikan terhadap willingness to trust dengan koefisien 0.431 dan mampu memediasi pengaruh variabel independent tersebut. Temuan ini sejalan dengan penelitian terdahulu (Wan, Zhang and Yan, 2020) yang menunjukkan bahwa dengan meningkatnya affective trust dan cognitive trust dapat meningkat willingness to choose dan sebaliknya. Baik affective trust dan cognitive trust merupakan hal yang penting untuk diperhatikkan untuk meningkatkan tingkat willingness to choose konsumen pada aplikasi layanan kesehatan. Karenanya manajemen konsultasi Kesehatan online perlu memperhatikan kedua aspek mediasi tersebut untuk meningkatkan standar pelayanan konsultasi Kesehatan online yang terpercaya. Konsultasi kesehatan online memiliki sejumlah keuntungan utama yang dapat meningkatkan tanggap darurat bila ada bahaya lingkungan atau biologis. Selama wabah penyakit menular, konsultasi 
kesehatan online dapat memungkinkan triase perawatan jarak jauh dan menyediakan informasi yang dapat diakses dengan cepat melalui teknologi.(Smith et al., 2020)

\section{KESIMPULAN}

Pasien yang menggunakan konsultasi kesehatan online, umumnya lebih banyak berjenis kelamin perempuan. Pasien tersebut didominasi oleh Usia dibawah 20 tahun, dengan berdomisili Di Jabodetabek. usia tersebut merupakan usia pelajar/mahasiswa. Hal tersebut dapat dihubungkan dengan banyaknya masyarakat berusia muda yang lebih sering menggunakan Gadget serta aplikasi-aplikasi secara online.Terkait hal tersebut dapat disarankan bagi manajemen konsultasi pelayanan kesehatan online untuk menawarkan program pelayanan konsultasi kesehatan berkualitas konsumen. pasien tentunya ingin mendapatkan pengalaman konsultasi kesehatan online yang efisien dengan dokter yang profesional sebagai pendamping kesehatannya. program tersebut harus merupakan layanan berkualitas yang berempati serta menyeluruh antara cara hubungan dokter-pasien dalam platform konsultasi kesehatan online dimana terjadi kontak tidak langsung dengan konsumen yaitu pasien. hal tersebut perlu didukung dengan fasilitas serta integritas yang membuat pasien dapat percaya untuk memberikan informasinya Melalui media daring. Terdapat delapan faktor yang mempengaruhi kesediaan pasien dalam melakukan konsultasi kesehatan online. Delapan faktor tersebut yaitu professional knowledge, physician rank, treatment effect, physician image, response speed, service commitment, service attitude, communication effort. Seluruh faktor tersebut merupakan hal yang penting untuk diperhatikan bagi manajer pelayanan konsultasi kesehatan online agar dapat menimbulkan kepercayaan pasien baik secara kognitif maupun afektif. Kepercayaan konsumen sangat dipengaruhi oleh kualitas layanan yang diberikan oleh dokter sebagai pelayan jasa dalam platform konsultasi kesehatan online tersebut. saat menerima pelayanan, pasien berada dalam situasi si mencari pertolongan terhadap masalah kesehatan yang dihadapi. kekurangan fisik merupakan hal yang sensitif sehingga diperlukan kompetensi dan profesionalitas yang baik untuk menghindari hal yang tidak sesuai harapan. rasa percaya yang timbul dari pasien saat menjalankan konsultasi kesehatan online menjadi di faktor yang penting agar pasien mau kembali berkonsultasi secara online. Oleh sebab itu Manajer pelayanan kesehatan online disarankan untuk dapat memfokuskan Resort dan budget untuk meningkatkan kualitas pelayanan dari segi mutu pelanggan internal, dalam hal ini adalah dokter. hal yang dapat dilakukan misalnya dengan merekrut dokter yang berpengalaman dalam menggunakan teknologi, mampu berkomunikasi dengan baik serta memiliki empati terhadap pasien. pelatihan komunikasi serta pembaharuan ilmu kedokteran dapat dilakukan untuk meningkatkan pengelolaan sumber daya manusia agar terjadi peningkatan keterampilan dan kepekaan dokter sebagai pemberi layanan konsultasi kesehatan online. bila kinerja dokter sudah melebihi standar pelayanan, pemberian insentif atau reward perlu dipertimbangkan dalam rangka menjaga motivasi dan komitmen seorang 
dokter dalam melakukan pelayanan konsultasi online tersebut. Kepercayaan pasien terhadap pelayanan dokter dalam melakukan konsultasi kesehatan online baik secara kognitif maupun afektif mempunyai dampak yang nyata pada willingness to choose konsultasi kesehatan online. pengalaman pasien ketika melakukan konsultasi kesehatan online akan melekat di dalam benak pasien tersebut. Oleh karena itu Manajer pelayanan harus senantiasa memantau atau mengevaluasi kepuasan konsumen tersebut. Dari survei rutin yang dilakukan dan didapatkan Umpan balik dari pasien terkait hal yang perlu ditingkatkan dan perlu dipertahankan. kemudian manajemen dapat mengevaluasi standar prosedur pelayanan konsultasi kesehatan online yang telah disusun sesuai umpan balik tersebut. dalam menghadapi pandemi covid-19, konsultasi kesehatan online merupakan suatu sarana yang sangat diperlukan dalam meningkatkan mutu pelayanan kesehatan secara nasional. dengan rasa kepercayaan yang tinggi secara kognitif dan afektif akan kembali melakukan konsultasi kesehatan online, dimana hal tersebut dapat memberikan manfaat jangka panjang pada platform konsultasi kesehatan online. bila pasien memiliki kesetiaan yang baik untuk memilih melakukan konsultasi kesehatan secara online maka dapat menjadi sarana promosi yang efektif bagi penyedia konsultasi kesehatan online dan memberikan Efek loyalitas yang didapatkan kan oleh penyedia konsultasi kesehatan online tersebut.

\section{DAFTAR PUSTAKA}

Alhelalat, J. A., Habiballah, M. A. and Twaissi, N. M. (2017) 'The impact of personal and functional aspects of restaurant employee service behaviour on customer satisfaction', International Journal of Hospitality Management. Elsevier Ltd, 66, pp. 46-53. doi: 10.1016/j.ijhm.2017.07.001.

Baert, S. (2018) 'Facebook profile picture appearance affects recruiters' first hiring decisions', New Media and Society, 20(3), pp. 1220-1239. doi: 10.1177/1461444816687294.

Bauman, A. and Bachmann, R. (2017) 'Online consumer trust: Trends in research', Journal of Technology Management and Innovation, 12(2), pp. 68-79. doi: $10.4067 / \mathrm{S} 0718$ 27242017000200008.

Bull, T. P. et al. (2016) 'Considerations for the telehealth systems of tomorrow: An analysis of student perceptions of telehealth technologies', JMIR Medical Education, 2(2). doi: 10.2196/mededu.5392.

Campbell, J. et al. (2019) 'Client, provider and community referrer perceptions of telehealth for the delivery of rural paediatric allied health services', Australian Journal of Rural Health, 27(5), pp. 419-426. doi: 10.1111/ajr.12519.

Chaet, D. et al. (2017) 'Ethical practice in Telehealth and Telemedicine', Journal of General Internal Medicine. Journal of General Internal Medicine, 32(10), pp. 1136-1140. doi: 10.1007/s11606017-4082-2. 
Chandon, A. H. M. J. D. W. A. J.-L. (2016) 'Article information: Affective trust in buyer - seller relationships: A twodimensional scale', Journal of Business and Industrial Marketing, 31(2), p. 3.

Chatzi, A. V. et al. (2019) 'The unexplored link between communication and trust in aviation maintenance practice', Aerospace, 6(6), pp. 1-18. doi: 10.3390/aerospace6060066.

Chen, Y.-C. et al. (2017) 'Measuring quality variations in e-service', Journal of Service Theory and Practice, 27(2), pp. 427-452.

Cheng, X., Fu, S. and de Vreede, G. J. (2017) 'Understanding trust influencing factors in social media communication: A qualitative study', International Journal of Information Management. Elsevier Ltd, 37(2), pp. 25-35. doi: 10.1016/j.ijinfomgt.2016.11.009.

Daskivich, T. J. et al. (2018) 'Online physician ratings fail to predict actual performance on measures of quality, value, and peer review', Journal of the American Medical Informatics Association, 25(4), pp. 401-407. doi: 10.1093/jamia/ocx083.

Delloitte (2020) Deloitte releases its 2020 Global Health Care Outlook, Delloitte. Available at: https://www2.deloitte.com/xe/en/pages /life-sciences-andhealthcare/articles/deloitte-releases-its2020-global-health-care-outlook.html (Accessed: 27 February 2021).

Deloitte (2018) 21 st Century Health Care Challenges: A Connected Health Approach. Indonesia.
Dwyer, J. (2018) 'Understand Communication Practice', in Alford, G. (ed.) The Business Communication Handbook. 11th edn. Australian: Cengage Learning, p. 6.

Eisenstein, E. et al. (2020) 'Telemedicine: a Bridge Over Knowledge Gaps in Healthcare', Current Pediatrics Reports. Current Pediatrics Reports, 8(3), pp. 93-98. doi: 10.1007/s40124020-00221-w.

Ert, E., Fleischer, A. and Magen, N. (2016) 'Trust and reputation in the sharing economy: The role of personal photos in Airbnb', Tourism Management. Elsevier Ltd, 55, pp. 62-73. doi: 10.1016/j.tourman.2016.01.013.

Fagerstrøm, A. et al. (2017) 'That personal profile image might jeopardize your rental opportunity! On the relative impact of the seller's facial expressions upon buying behavior on Airbnb ${ }^{\mathrm{TM}}$, Computers in Human Behavior, 72, pp. 123-131. doi: 10.1016/j.chb.2017.02.029.

Falah, F. and Syamsidar (2021) 'Pengaruh Penerapan Aplikasi Chatbot Sebagai Media Informasi Online Terhadap Kepuasan Pengguna Layanan Kesehatan Primer Di Masa Pandemik Covid - 19', Bina Generasi; Jurnal Kesehatan, 12(2), pp. 18-23.

Filieri, R. (2016) 'What makes an online consumer review trustworthy?', Annals of Tourism Research. Elsevier Ltd, 58, pp. 46-64. doi: 10.1016/j.annals.2015.12.019.

Haddock, G. and Maio, G. (2017) 'Attitude', in Turner, B. S. (ed.) The Wiley Blackwell Encyclopedia of Social 
Theory. New YORK: John Wiley and Sons, Ltd, p. 2. doi: 10.1002/9781118430873.est0018.

Haimi, M. et al. (2020) 'Assessing patient safety in a pediatric telemedicine setting: A multi-methods study', $B M C$ Medical Informatics and Decision Making. BMC Medical Informatics and Decision Making, 20(1), pp. 1-14. doi: 10.1186/s12911-020-1074-7.

Hair, J. F. et al. (2018) 'When to use and how to report the results of PLS-SEM', European Business Review, 31(1), pp. 2-24.

Hair, J. F., Howard, M. C. and Nitzl, C. (2020) 'Assessing measurement model quality in PLS-SEM using confirmatory composite analysis', Journal of Business Research. Elsevier, 109(November 2019), pp. 101-110. doi: 10.1016/j.jbusres.2019.11.069.

Hall, J. A., Ruben, M. A. and Swatantra (2020) 'First Impressions of Physicians According to Their Physical and Social Group Characteristics', Journal of Nonverbal Behavior. Springer US, 44(2), pp. 279-299. doi: 10.1007/s10919-019-00329-8.

Huang, X., Kwiatkowska, M. and Olejnik, M. (2019) 'Reasoning about Cognitive Trust in Stochastic Multiagent Systems', ACM Transactions on Computational Logic, 20(4), pp. 21:161. doi: 10.1145/3329123.

Istanbulluoglu, D. (2017) 'Complaint handling on social media: The impact of multiple response times on consumer satisfaction', Computers in Human Behavior. Elsevier B.V., 74, pp. 72-82. doi: 10.1016/j.chb.2017.04.016.
Iwai, T. and Azevedo, P. F. De (2016) 'Economic Incentives or Communication: How Different Are their Effects on Trust', Brazilian Administration Review, 13(3), pp. 125.

Job, C., Yan Wong, K. and Anstey, S. (2019) 'Patients' stories in healthcare curricula: creating a reflective environment for the development of practice and professional knowledge', Journal of Further and Higher Education. Routledge, 43(5), pp. 722728.

doi: 10.1080/0309877X.2017.1404559.

Karimi, S. and Wang, F. (2017) 'Online review helpfulness: Impact of reviewer profile image', Decision Support Systems. Elsevier B.V., 96, pp. 39-48. doi: 10.1016/j.dss.2017.02.001.

Kemenkes (2019) Peraturan menteri kesehatan republik indonesia nomor 20 tahun 2019 tentang penyelenggaraan pelayanan. Jakart.

Khemapech, I. et al. (2019) 'Telemedicine Meaning , Challenges and Opportunities', 71(3), pp. 246-252.

Kim, J. M., Kim, M. and Key, S. (2020) 'When profile photos matter: the roles of reviewer profile photos in the online review generation and consumption processes', Journal of Research in Interactive Marketing, 14(4), pp. 391412. doi: 10.1108/JRIM-10-2019-0163.

Kock, N. and Hadaya, P. (2018) 'Minimum sample size estimation in PLS-SEM: The inverse square root and gammaexponential methods', Information Systems Journal, 28(1), pp. 227-261. doi: 10.1111/isj.12131. 
Kulgemeyer, C. and Riese, J. (2018) 'From professional knowledge to professional performance: The impact of $\mathrm{CK}$ and PCK on teaching quality in explaining situations', Journal of Research in Science Teaching, 55(10), pp. 13931418. doi: $10.1002 /$ tea.21457.

Lemeshow, S. et al. (1990) Adequacy of Sample Size in Health Studies., World Health Organization. doi: $10.2307 / 2532527$.

Liu, J. J., Justin Matelski, J. and Bell, C. M. (2018) 'Scope, breadth, and differences in online physician ratings related to geography, specialty, and year: Observational retrospective study', Journal of Medical Internet Research, 20(3), pp. 1-13. doi: 10.2196/jmir.7475.

Lu, T., Xu, Y. C. and Wallace, S. (2018) 'Internet usage and patient's trust in physician during diagnoses: A knowledge power perspective', Journal of the Association for Information Science and Technology, 69(1), pp. 110-120. doi: 10.1002/asi.23920.

Ly, B. A. et al. (2017) 'The individual and contextual determinants of the use of telemedicine: A descriptive study of the perceptions of Senegal's physicians and telemedicine projects managers', $P L O S$ ONE, 12(7), pp. 1-18. doi: 10.1371/journal.pone.0181070.

McCartney, G. et al. (2019) 'Defining health and health inequalities', Public Health. Elsevier Ltd, 172, pp. 22-30. doi: 10.1016/j.puhe.2019.03.023.

McClellan, M. J. et al. (2020) 'Clinician telehealth attitudes in a rural community mental health center setting.', Journal of Rural Mental Health, 44(1), pp. 62-73. doi: 10.1037/rmh0000127.

MTPC (2020) Digital Health in Indonesia: Opportunities for Australia. Australian. Obele, C. C. et al. (2017) 'What Patients Think About Their Interventional Radiologists: Assessment Using a Leading Physician Ratings Website', Journal of the American College of Radiology. Elsevier Inc, 14(5), pp. 609-614. doi: 10.1016/j.jacr.2016.10.013.

Punyatoya, P. (2019) 'Effects of cognitive and affective trust on online customer behavior', Marketing Intelligence and Planning, 37(1), pp. 80-96. doi: 10.1108/MIP-02-2018-0058.

Renedo, A., Komporozos-Athanasiou, A. and Marston, C. (2018) 'Experience as Evidence: The Dialogic Construction of Health Professional Knowledge through Patient Involvement', Sociology, 52(4), pp. 778-795. doi: $10.1177 / 0038038516682457$.

Robbins, B. G. (2016) 'What is Trust? A Multidisciplinary Review, Critique, and Synthesis', Sociology Compass, 10(10), pp. 972-986. doi: 10.1111/soc4.12391.

Ruiz Morilla, M. D. et al. (2017) 'Implementing technology in healthcare: Insights from physicians', $B M C$ Medical Informatics and Decision Making. BMC Medical Informatics and Decision Making, 17(1), pp. 1-9. doi: 10.1186/s12911017-0489-2.

Sarstedt, M. and Christian M. Ringle, and J. F. H. (2017) Partial least squares 
structural equation modeling with $R$, Practical Assessment, Research and Evaluation.

Shulver, W., Killington, M. and Crotty, M. (2016) "Massive potential" or "safety risk"? Health worker views on telehealth in the care of older people and implications for successful normalization', $\quad B M C \quad$ Medical Informatics and Decision Making. BMC Medical Informatics and Decision Making, 16(1), pp. 1-15. doi: 10.1186/s12911-016-0373-5.

Similarweb (2021) Halodoc.com, Similarweb. Available at: https://www.similarweb.com/website/h alodoc.com/\#nverview (Accessed: 23 May 2021).

Smith, A. C. et al. (2020) 'Telehealth for global emergencies: Implications for coronavirus disease 2019 (COVID19)', Journal of Telemedicine and Telecare, 26(5), pp. 309-313. doi: 10.1177/1357633X20916567.

Stephanie Allen, P. et al. (2019) '2019 Global health care outlook Shaping the future', Design Issues, p. 41. Available at:

https://www2.deloitte.com/content/da $\mathrm{m} /$ Deloitte/global/Documents/LifeSciences-Health-Care/gx-lshc-hcoutlook2019.pdf\%0Ahttp://www.ncbi.nlm.nih. gov/books/NBK2665/\%0Ahttp://dx.do i.org/10.1016/j.bios.2016.09.038\%0Ah ttps://pdfs.semanticscholar.org/956b/6 ee61.

Sunjaya, A. P. (2019) 'Potensi, Aplikasi dan Perkembangan Digital Health di Indonesia', Journal of Indonesian
Medical Association, 69(April), pp. 167-169.

Wade, V. A. et al. (2016) 'Transitioning a home telehealth project into a sustainable, large-scale service: A qualitative study', BMC Health Services Research. BMC Health Services Research, 16(1), pp. 1-10. doi: 10.1186/s12913-016-1436-0.

Wan, Y., Zhang, Y. and Yan, M. (2020) 'What influences patients' willingness to choose in online health consultation? An empirical study with PLS-SEM', Industrial Management and Data Systems, 120(12), pp. 2423-2446. doi: 10.1108/IMDS-11-2019-0633.

Yahaya, R. and Ebrahim, F. (2016) 'Leadership styles and organizational commitment: literature review', Journal of Management Development, 35(2), pp. 190-216. doi: 10.1108/JMD01-2015-0004.

Zayapragassarazan, Z. and Kumar, S. (2016) 'Awareness, knowledge, attitude and skills of telemedicine among health professional faculty working in teaching hospitals', Journal of Clinical and Diagnostic Research, 10(3), pp. JC01-JC04. doi: 10.7860/JCDR/2016/19080.7431. 